\title{
Secondary Metabolite Production by Trichoderma spp and its Potential as Antibacteria
}

\author{
Nurbailis*, Akmal Djamaan, Haliatur Rahma and Yenny Liswarni
}

Andalas University, Limau Manis Campus Padang, Indonesia

*Corresponding author

\begin{tabular}{|l|}
\hline Ke y w o r d s \\
Colony, Filtrate, \\
$\begin{array}{l}\text { Trichodermaspp, } \\
\text { Xanthomonas } \\
\text { axanopodis pv. alii }\end{array}$ \\
\hline Article Info \\
\hline $\begin{array}{l}\text { Accepted: } \\
\text { 04 March } 2019 \\
\text { Available Online: } \\
\text { 10 April } 2019\end{array}$ \\
\hline
\end{tabular}

Trichoderma can produce secondary metabolites which act as anti-bacteriawhichpotential to be used for controlling the plant pathogen like Xanthomonas axanopodis pv. alii. The purpose of this study was to known the best interaction beetween the filtrates of Trichoderma spp and cocentration of the filtrate for reducing the growth of $\mathrm{X}$. axanopodis pv. alii caused leaf blight disease on red onion. The method of secondary metabolite production of Trichoderma spp was the single culture. The design used was factorial in a complete randomized design with 2 factors and 4 replications. The first factor was the filtrate originating from Trichoderma spp, i.e. T. harzianum, T. koningii and T. viride and the second factor was the concentration of Trichoderma spp, i.e. $0 \%, 25 \%, 50 \%, 75 \%$ and $100 \%$. Parameters observed were: wide of clear zone, the amount of colony and the growth rate of of $X$. axanopodis. The result show that all Trichoderma filtrate can inhibit the growth of $X$. axanopodis pv. alii. The higher of concentration the more depressed the pathogen growth. The interaction between the filtrate and the concentration indicated that the filtrate of T. harzianum with a concentration of $100 \%$ could inhibit the total growth of $X$. axanopodis $p v$. alii.

\section{A B S T R A C T}

\section{Introduction}

Bacterial leaf blight disease caused by Xanthomonas axanopodis pv. alii (Xaa) is an important disease on onion (Kadota et al, 2000; Roumanag et al, 2004; Habazar et al., 2007). Loss of the yield due to the attack of this pathogen can reach $100 \%$ especially if suitable environment (Schwart and Gent, 2006).

Some methods that have been carried out for controlling this pathogen are: crop rotation with the non-hosts, resistant varieties, healthy seeds and chemical control using bactericides (Paulraj and Garro, 1993; Schwartz and Gent, 2006). In Indonesia, information about controlling this pathogen is still limited. For this reason, it is necessary to develop various research methods that environmentally friendly, one of which is to use a biopesticide derived from Trichoderma spp.

Trichoderma is one of the soil fungi that is antagonistic to various pathogens that cause plant disease (Cook and Baker, 1983; Nurbailis, 1992; Harman, 2006; Pusvapavathi et al., 2016). This mechanism of antagonism 
is competition, mycoparasites, and antibiosis (Cook and Baker, 1983; Howell, 2003; Nurbailis, 2008). Nurbailis et al., (2006) reported that $T$. viride and $T$. harzianum isolates from banana rhizosphere were able to inhibit the growth of $F$. oxysporum f.sp. cubense with the antibiosis mechanism.

Antibiosis is a mechanism of antagonistic fungi that can inhibit the growth of pathogens with antagonistic chemical products that produced and released by Trichoderma into their environment, There are extra cellular enzyme systems, antibiotics which damage the pathogens (Cook and Baker 1983; Leelavathy et al., 2014) Antibiotic compounds can be used as an alternative to substituting artificial pesticides for controlling plant pathogens

Trichoderma spp produces secondary metabolites which act as antifungal and antibacterial such as polyketides, pyrones, and terpenes (Naher et al., 2014). Leelavathy et al., (2014) reported that crude extracts of $T$. harzianum with different concentrations can inhibit the growth of various pathogenic bacteria. Effective concentration in inhibiting the growth of Staphylococcus aureus, Escheria coli and Klebsiella was $100 \mu \mathrm{l} / \mathrm{ml}$ with clear zone area $1.8-2.0 \mathrm{~cm}$. Basiriya et al., (2017) report that secondary metabolites (crude extract) from Trichoderma spp indigenoes mangrove rhizosphere inhibited the growth of $S$. aereus, E. coli and Pseudomonas auregenesa. The best isolates were T. harzianum (1) and T. viride.

The development of using Trichoderma spp which indicates the presence of an antibiosis mechanism for controlling Xaa on red onion requires the research about Utilization of secondary metabolites from Trichoderma spp to inhibit the growth of Xaa. The purpose of this research were to obtain superior Trichoderma isolates which is capable to produce secondary metabolites which act as antibacterial compounds and the best concentration for inhibiting the growth of Xanthomonas axonopodis pv. allii.

\section{Materials and Methods}

The research was conducted at the Microbiology laboratory of the Faculty of Agriculture Andalas University, Padang from April to November 2018.This research used factorial in Complete Randomized Design which consist of 2 factors, 15 treatment combinations and 3 replications was employed in this study. The first factor was the filtrate (secondary metabolite) of Trichoderma spp, ie: T. viride, T. harzianum and Trichoderma PP3. The second factor were the filtrate concentration which consist of $0 \%, 25 \%, 50 \%, 75 \%$ and $100 \%$. The data were analyzed by variance and with continued Duncan's multiple distance test (DNMRT) at a 5\% significance level

\section{Implementation}

\section{Propagation of Trichoderma spp.}

Trichoderma spp.: T. viride, T. harzianum, $T$. koningii, which had been shown antibiosis mechanism, were propagated in Potato Dextrosa Agar medium and incubatedin room temperature for 7 days.

\section{Propagation of Trichoderma spp in liquid culture}

Trichoderma was propagated in liquid culture in Potato Dextrosa Broth medium. For every 1 liter of medium used as much as $100 \mathrm{ml}$ of starter (10\% total volume) and incubated for five days at room temperature, then the culture was incubated using a shaker at a speed of $180 \mathrm{rpm}$ for 7 days. (Kumar et al, 2014). 
Preparation of secondary metabolite of Trichoderma spp

Trichoderma spp were propagated in a liquid medium as mentioned above, used to obtain filtrate by separating the liquid culture between the hifa and the filtrate by using What man filter paper, then centrifuged at $4000 \mathrm{rpm}$ for 30 minutes. The filtrate was filtered again with What man paper into another test tube, finally a milipore filter membrane $(0.2 \mu \mathrm{m})$ was used for filtering the filtrate.

\section{Preparation of Xanthomonas axonopodis pv. allii Culture}

Xantthomonas axanopodis pv. alii was obtained from the collection of the Laboratory of Microbiology, Faculty of Agriculture, Andalas University, were rejuvenated on Nutrient Glucose Agar (NGA) medium by scratching method and incubated for 48 hours at room temperature

Treatment of Trichoderma filtrate against Xanthomonas axonopodis pv. allii

Trichoderma filtrate was prepared with various concentrations, each of filtrate was taken $1 \mathrm{ml}$ and mixed evenly with $9 \mathrm{ml}$ of NGA medium which was still hot $\left(45^{\circ} \mathrm{C}\right)$, then the medium was cooled. The Xanthomona saxonopodis pv. allii $\left(10^{-4}\right.$ cells / $\mathrm{ml}$ ), Spread on the medium and incubated for 48 hours at room temperature.

Testing of Xanthomonas axonopodis pv. allii growth inhibition carried out byusing sterile disc paper, filter paper is cut circularly with a diameter of $0.5 \mathrm{~cm}$,soaked into each filtrate for 5 minutes, placed on streaks of Xanthomonas axonopodis pv. allii in petri dishes and incubated for 24 hours at room temperature, for a control was used sterile aquades.

\section{Observation}

Inhibitory Power of Trichoderma Filtrate againts $X$. axanopodis pv. alii Growth

The inhibitory power of Trichoderma filtrate against $X$. axanopodis pv. Alii $X$. axanopodis pv. alii growth is done by carving a clear zone formed on paper discs that contain Trichoderma spp filtrate. Measurements are made by drawing the area of the clear zone formed on transparant plastic and measured with a ruler.

Number of $X$. axanopodis pv. alii colonies by treatment with Trichoderma filtrate

Observation of the number of colonies was carried out by counting the number of $X$. Axanopodis pv. alii colonies by using colony counter, observations carried out at 12, and 24 hours after inoculation.

\section{Results and Discussion}

Growth inhibition of X.axanopodis pv. alii that treated with Trichoderma filtrate

In general, secondary metabolites ofTrichoderma spp could form a clear zone for inhibition of X.axanopodis pv. alii growth. The area of clear zone is different between isolates and concentrations (Table 1).

The formation of a clear zone indicates that the secondary metabolites produced by Trichoderma spp contains anti-bacterial compounds. $T$. viride and $T$. harzianum isolates form higher clear zones compared with Trichoderma PP3. According to Naher et al (2012) some secondary metabolites produced by Trichoderma spp such as polyketides, pyrones, and terpenes act as antibacterial and anti fungal. Basiria et al (2017) reported that $T$. harzianum (1) and $T$. viride could inhibit the growth of gram + 
staphylococcus aureus and gram negative Escheria coli.

The number of Xanthomonas axanopodis pv.alii colonies treated with the Trichoderma spp. filtrate

The number of $X$. axanopodis pv.alii colonies with the treatment with various concentrations of Trichoderma spp. showed significant differences between 12 hours and 24 hours incubation (Table 2 and 3).

T. harzianum filtrate showed the better inhibition of $X . \quad$ axanopodis pv.aliicolonization growth than T.viride filtrate and Trichoderma PP3. The treatment of $T$. harzianum filtrate with the concentration of $25 \%$ could reduce the number of $X$. axanopodis pv.alii colonies compared with without filtrate (control). Increased the concentration of Trichoderma spp. filtrate $50 \%$ and $100 \%$ the growth of $X$. axanopodis pv.alii colonies becomes zero or $X$. axanopodis pv.alii could not grow. This showed that the secondary metabolites produced by $T$. harzianum contain antibacterial compounds that could inhibit the growth of $X$. axanopodis pv.alii. Leelavathy et al., (2014) reported that the secondary metabolites or crude extracts of $T$. harzianum could inhibit the growth of various pathogenic bacteria Staphylococcus aureus, E coli, Klebsiella, effective concentration of $100 \mu \mathrm{l} /$ $\mathrm{ml}$ aquades.

Table.1 Area of clear zone of growth inhibition of Xanthomonas axanopodis pv.alii with various concentrations of Trichoderma spp filtrate in 12 hours incubation

\begin{tabular}{|l|c|c|c|c|c|}
\hline \multirow{2}{*}{$\begin{array}{l}\text { The Kind of } \\
\text { Filtrate }\end{array}$} & \multicolumn{5}{|c|}{ Area of Clear Zone (mm) } \\
\cline { 2 - 6 } & $\mathbf{0}$ & $\mathbf{2 5}$ & $\mathbf{5 0}$ & $\mathbf{7 5}$ & $\mathbf{1 0 0}$ \\
\hline $\boldsymbol{T}$. harzianum & 0.00 & $1.0 \mathrm{ab}$ & $6.0 \mathrm{~b}$ & $6.0 \mathrm{~b}$ & $6.0 \mathrm{~b}$ \\
\hline $\boldsymbol{T}$. viride & 0.00 & $6.0 \mathrm{~b}$ & $8.0 \mathrm{ab}$ & $6.0 \mathrm{~b}$ & $8.0 \mathrm{ab}$ \\
\hline $\begin{array}{l}\text { Trichoderma } \\
\text { PP3 }\end{array}$ & 0.00 & $4.0 \mathrm{~b}$ & $4.0 \mathrm{~b}$ & $1.0 \mathrm{ab}$ & $4.0 \mathrm{ab}$ \\
\hline
\end{tabular}

The numbers followed by the same lowercase letter on the same lane are not significantly different according to DMNRT level 5\%

Table. 2 The number of Xanthomonas axanopodis pv.alii colonies treated with various concentration of Trichoderma spp. filtrate in 12 hours incubation

\begin{tabular}{|c|c|c|c|c|c|}
\hline \multirow{3}{*}{$\begin{array}{l}\text { The Kind of } \\
\text { Filtrate }\end{array}$} & \multicolumn{5}{|c|}{$\begin{array}{l}\text { The amount of Xanthomonas axanopodis pv.alii colony } \\
\qquad 10^{4} \mathrm{cell} / \mathrm{ml}\end{array}$} \\
\hline & \multicolumn{5}{|c|}{ Filtrate cocentration $(\%)$} \\
\hline & 0 & 25 & 50 & 75 & 100 \\
\hline T. harzianum & $33.66 \mathrm{a}$ & $10.66 \mathrm{ab}$ & $0.00 \mathrm{c}$ & $0.00 \mathrm{c}$ & $0.00 \mathrm{c}$ \\
\hline T. viride & $33.66 \mathrm{a}$ & $33.66 \mathrm{a}$ & $26.66 \mathrm{ab}$ & $12.00 \mathrm{bc}$ & $0.00 \mathrm{c}$ \\
\hline $\begin{array}{l}\text { Trichoderma } \\
\text { PP3 }\end{array}$ & $33.66 \mathrm{a}$ & $27.66 \mathrm{ab}$ & $14.00 \mathrm{bc}$ & $16.66 \mathrm{bc}$ & $26.66 \mathrm{ab}$ \\
\hline
\end{tabular}

The numbers followed by the same lowercase letter on the same lane are not significantly different according to DMNRT level 5\% 
Table.3 The number of Xanthomonas axanopodis pv. alii colonies treated with various concentration of Trichoderma spp. Filtrate in 24 hours incubation

\begin{tabular}{|l|c|c|c|c|c|}
\hline \multirow{2}{*}{\begin{tabular}{l}
\multirow{2}{*}{$\begin{array}{c}\text { The Kind of } \\
\text { Filtrate }\end{array}$} \\
\end{tabular}} & \multicolumn{5}{|c|}{ The amount ofXanthomonas axanopodis } \\
$\mathbf{1 0}^{\mathbf{4}}$ cell/ml
\end{tabular}

The numbers followed by the same lowercase letter on the same lane are not significantly different according to DMNRT level 5\%

The secondary metabolites produced by $T$. viride at the concentration of $25 \%$ were not able to inhibit the growth of $X$. axanopodis pv.alii. This can be seen in the incubation period of 12 hours the number of $X$. axanopodis pv.alii colonies was the same as the control treatment, namely 33.66. $10^{4} \mathrm{sel} / \mathrm{ml}$ suspension. This shows that the concentration of $25 \%$ did not affect the growth of $X$. axanopodis pv.alii. Increasing the cocentration $50 \%-75 \%$ caused a decrease the growth of $X$. axanopodis pv.alii to 45.66 and 24.66 cells / $\mathrm{ml}$ suspension and at concentration $100 \% \quad X$. axanopodis pv.alii growth to be zero. Basiriya et al., (2017) report that secondary metabolites (crude extract) of $T$. harzianum and $T$. viride indigenoes mangrove rhizosphere were the good isolatesin inhibiting the growth of S.aereus, E. coli and Pseudomonas auregenesa.

In conclusion, Trichodermas pp. filtrate couldinhibit the growth of $X$. axanopodis $\mathrm{pv}$. alii. The higher of concentration the more depressed the pathogen growth.The interaction between the filtrate and the concentration indicated that the filtrate of T. harzianum with a concentration of $100 \%$ could inhibit the total growth of $X$. axanopodispv. alii

\section{References}

Basiriya, R.H.M., Anuswedha, A., Kalaiselvam, M. 2017. Antibacterial efficasy of crude extract of Trichoderma spp isolated from Mangrove rhizosphere. Int.Res.J.
Pharm., 8 (8) : $70-73$

Cook, R. J., and Baker, K. F. 1983. The nature and practice of biological control of plant pathogens. Amer. Phytopathology. Soc., St, Paul, Minnesota

Habazar, T, Nasrun, Jamsari, Rusli, I., 2007. Polapenyebaranpenyakithawardaunbakt eri (Xanthomonas axanopodis pv. allii) padabawangmerahdanupayapeng endaliannyamelaluiimunisasimengguna kan rhizobacteria. Laporanhasil penelitian KKP3T. Universitas AndalasbekerjasamadenganSekretariatB adanPenelitiandanpengembanganpertani an.

Harman, G. E. 2000. Changes in Perceptions Derived from Research on Trichodermaharzianum T-22. Plant Disease / April 2000. Publication No. D-2000-0208-01F.

Howell C. R. 2003. Mechanism employed by Trichoderma species in the Biological control of plant disease: The history and evolution of current concepts. USDA/ARS Southern Plains Agricultural Research Center.

Junianto, Y.D., danSukamto, S. 1995. Pengaruhsuhudankelembabanrelatifterh adapperkecambahan, pertumbuhandan sporulasibeberapa isolat Beauveria bassiana. Pelita Perkebunan 11(2).6475.

Kadota I, Uehara K, Shinohara H and Nishiyama K (2000) Bacterial blight of 
Welsh onion, A new disease caused by Xanthomonascampestris pv. allii pv. nov. Journal of General Plant Pathology 66, 310-315.

Kim, K. H, J. B. Yoon, E. W. Park and Y. H. Kim. 2004. Structure Modification and Programmed Cell Death of Chili Pepper Fruit Related to Resistance Responses to Colletotrichum gloeosporioides Infection. J. Phytopathology. 82: 213225.

Leelavathy, MS. Vani, L and Reena, P. 2014. Antimicrobial activity of Trichoderma harzianum against bacteria and fungi. International Journal of current microbiology and Applied Science (3)1: 96-103

Lorito, M., Harman, G.E., Hayes, C.K., Broadway, R.M., Tronsmo, A., Woo, S.L. and Di Pietro, A. (1993). Chitinolytic enzyme produced by Trichoderma harzianum. Anti fungal activity of purified endochitinase and chitibiosidase. Phytopathology, 83: 302-307

Naher, L., Yusuf, UK., Ismail, A and Hossain K. 2014. Trihoderma spp: A Biocontrol agenst for sustainable management of plant disease . Pak. J. Bot 46 (4); 1489 1493.

Nurbailis, Mardinus, Nasril, N. Dharma, A., 2006. Penapisan Isolat Trichoderma yang berasal dari rizosfir tanaman pisang di Sumatera Barat untuk pengendalian penyakit layu Fusarium. Journal Akta Agrosia. (9)1.

Nurbailis. 1992. Pengendalian hayati Sclerotiumrolfsii penyebab penyakit busuk batang kacang tanah (Arachishypogaea L.) dengan kompos dan cendawan antagonis. Program Pascasarjana. IPB. Bogor.
Nurbailis, Mardinus, Nasir, N. Dharma, A. And Habazar, T. $2008 . \quad$ Penapisan Trichodermaspp dari Rizosfir pisang untuk menekanpertumbuhan Fusarium oxysporum f.sp.cubense in vitro. Journal of Manggaro, 9:16-21.

Paulraj, L. and L.W.O Garro. 1993. Leaf Blight of onion in Bardados caused by Xanthomonas campestris. Plant Disease. 86:3330

Roberts, P. D., Pernezny. K. L., and Kucharek, T. A. 2008. Antracnose Caused By Colletotrichum sp on Pepper. http://edis.ifas.ufl.edu/PP104

Roumagnac P, Gagnevin L, Gardan L, Sutra L, Manceau C, Dickstein ER (2004) Polyphasic characterization of xanthomonads isolated from onion, garlic and Welsh onion (Allium spp.) and their relatedness to different Xanthomonas species. International Journal of Systematic and Evolutionary Microbiology, 54, 15

Schwartz, I I. F., and Gent, D. H., 2006.Xanthomonas Leaf Blight of Onion (http//www.Extcolestate.edu/ push/gorden html access 22.02-2006).

Tijerino, A., Cardoza, R. E., Moraga, J., Malmierca, M. G., Vicente, F.Aleu, J. Collado, I. G., Gutierrez, S., Monte, E. \& Hermosa, R. (2011).Overexpression of the trichodiene synthase genetri 5 increases trichodermin production and antimicrobial activity in Trichoderma brevicompactum. Fungal Genet Biol48, 285-296

Woo, S.L., Scala, F., Ruocco, M., and M. Lorito, (2006). The molecular biology of the interactions between Trichoderma spp., phytopathogenic fungi and plants. Phytopathology 96, 181-185.

\section{How to cite this article:}

Nurbailis, Akmal Djamaan, Haliatur Rahma and Yenny Liswarni. 2019. Secondary Metabolite Production by Trichoderma spp and its Potential as Antibacteria. Int.J.Curr.Microbiol.App.Sci. 8(04): 196-201. doi: https://doi.org/10.20546/ijemas.2019.804.020 